\title{
Effects of sediment sulfides on seagrass Posidonia oceanica meristematic activity
}

\author{
Neus Garcias-Bonet ${ }^{1, *}$, Núria Marbà ${ }^{1}$, Marianne Holmer $^{2}$, Carlos M. Duarte $^{1}$ \\ ${ }^{1}$ Institut Mediterrani d'Estudis Avançats (CSIC-UIB), Miquel Marquès 21, 07190 Esporles, Spain \\ ${ }^{2}$ Institute of Biology, University of Southern Denmark, Campusvej 55, 5230 Odense M, Denmark
}

\begin{abstract}
Meristematic activity response of Posidonia oceanica shoots was assessed along a gradient of sediment sulfate reduction rates (SRR) and sediment sulfide pools (SSP) to test if meristematic activity could be used as an early indicator of seagrass health. The percentage of nuclei in the G2 phase of the cell cycle was used as a proxy of the cell division rate and therefore of the meristematic activity. The variability observed in the percentage of dividing cells (i.e. those containing nuclei in the G2 phase) in P. oceanica meristems was closely ( $>80 \%$ of total variance) coupled to variability in SSP and SRR. The percentage of nuclei in the G2 phase exponentially declined with increasing SSP and SRR, reaching the lowest values $(<5 \%)$ when plants were growing on sediments with SSP $>0.001 \mathrm{~mol}$ AVS (acid volatile sulfides) $\mathrm{m}^{-2}$. These results strongly suggest that the meristematic activity can be used as an early warning indicator of seagrass stress.
\end{abstract}

KEY WORDS: Posidonia oceanica - Caulerpa spp. invasions $\cdot$ Sediment sulfate reduction rate $\cdot$ Sediment sulfide pools $\cdot$ Seagrass decline $\cdot$ Meristematic activity Resale or republication not permitted without
written consent of the publisher

\section{INTRODUCTION}

Seagrass meadows rank amongst the most productive ecosystems on Earth, growing along tropical and temperate coasts, where they have important structural and biogeochemical functions (Hemminga \& Duarte 2000). Seagrasses are clonal plants, which expand into new areas vegetatively by adding modules produced by the meristems located at the rhizome apices, rendering seagrass demographics and productivity closely dependent on rhizome meristematic activity (Tomlinson 1974).

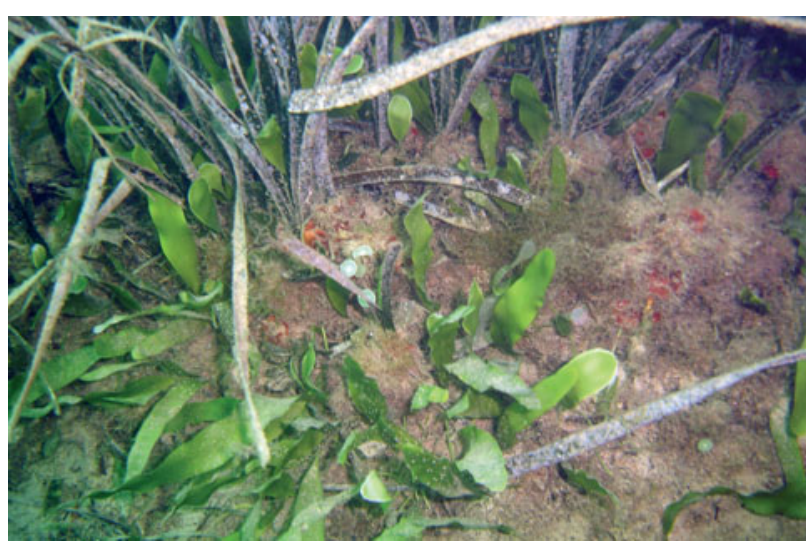

Increased sediment sulfides due to Caulerpa invasions decreases meristematic activity of the seagrass Posidonia oceanica.

Photo: Marianne Holmer

Currently, seagrass meadows are undergoing a worldwide decline, as reflected by losses in cover and density during the 20th century (e.g. Orth et al. 2006). Excess inputs of nutrients and organic matter have been identified as the main drivers of this decline (e.g. Orth et al. 2006). Organic carbon and nutrient inputs to the sediment stimulate bacterial activity, increasing sediment oxygen demand and the production of bacterial metabolites such as sulfides, which are toxic for seagrasses (Terrados et al. 1999). Several die-off events in subtropical Thalassia testudinum (Borum et al. 2005) and temperate Zostera marina (Goodman et al. 1995) seagrass meadows have been linked to episodes of high sediment sulfide concentrations. It has been suggested that Caulerpa spp. invasions accelerate the decline in Posidonia oceanica meadows, since these macroalgae species cause the 
sediment sulfate reduction rate (SRR) to increase by more than 3-fold, when compared with those in seagrass meadows (Holmer et al. 2004). The rate of decline in $P$. oceanica meadows is closely coupled to sediment sulfide pools (SSP), increasing when sulfide porewater concentration exceeds $10 \mu \mathrm{M} \mathrm{H}_{2} \mathrm{~S}$ (Calleja et al. 2007). There is evidence of sulfide intrusion in P. oceanica tissues when this species is growing in sediments with a high SRR (Frederiksen et al. 2007). The intrusion of sulfide into the meristematic zone is considered detrimental for the plants, as it inhibits cytochrome oxidase even at low concentrations (1 to $10 \mu \mathrm{M}$, Raven \& Scrimgeour 1997). Hence, seagrass health is compromised by anoxia and sulfide concentration in the rhizosphere (Terrados et al. 1999, Duarte et al. 2005), since the activity of seagrass meristems growing in sediments with high sulfide concentrations may be affected.

The activity of plant meristems can be analysed by measuring the percentage of dividing cells at a specific time point, as demonstrated for intact tissues of Nicotiana tabacum (Galbraith et al. 1983) and for cell suspensions of Solanum aviculare (Yanpaisan et al. 1998). Flow cytometry has been extensively used to quantify the DNA content of cells or isolated nuclei suspensions (e.g. Galbraith et al. 1983, Le Gall et al. 1993). Eukaryotic cells have a cell division cycle that is divided into the interphase and mitosis phase. The interphase consists of a G1 phase (post-mitotic phase), when the cell grows and synthesizes proteins and RNA; an S phase (DNA synthetic phase), when the DNA is replicated; and a G2 phase, when the cell has doubled the DNA content and the nuclear proteins and is preparing to enter the mitotic phase. The percentage of nuclei in the G2 phase provides information on the percentage of meristematic cells that are dividing. Hence, the percentage of nuclei in the G2 phase could be used as an indicator of meristematic activity and, thus, at declining percentages as an indicator of seagrass stress.

In the present study, we quantify the percentage of nuclei in each phase of the interphase of the cell cycle in rhizome meristems of the dominant Mediterranean seagrass Posidonia oceanica, growing alone or mixed with the native Caulerpa prolifera and invasive C. taxifolia or C. racemosa, in 3 meadows from the Balearic Islands (Spain). The $P$. oceanica examined grew on sediments encompassing the broad range of sediment sulfide concentrations and SRR reported for the Balearic Islands region (Holmer et al. 2003, Calleja et al. 2007). The percentage of nuclei in the interphase phases was quantified by using flow cytometer techniques and cell cycle analysis. We compare the variability found for the percentage of dividing cells, or nuclei in the G2 phase, with SSP and SRR to explore the potential use of meristematic activity as an early warning indicator of seagrass stress.

\section{MATERIALS AND METHODS}

Study site. This study was conducted at 3 Posidonia oceanica meadows in Mallorca (Balearic Islands, Spain) that were partially colonised by the autochthonous macroalgae Caulerpa prolifera in Cala Llonga $\left(39^{\circ} 22.03^{\prime} \mathrm{N}, 3^{\circ} 13.73^{\prime} \mathrm{E}\right)$, and the invasive $C$. taxifolia or C. racemosa in Cala d' Or $\left(39^{\circ} 22.164^{\prime} \mathrm{N}, 3^{\circ} 13.88^{\prime} \mathrm{E}\right)$ and in Cala Estancia $\left(39^{\circ} 32.13^{\prime} \mathrm{N}, 2^{\circ} 42.65^{\prime} \mathrm{E}\right)$, respectively. The $P$. oceanica meadow at Cala Llonga, located in a sheltered bay, at the entrance of a marina, is declining, as evidenced by large areas with dead rhizomes. It grows at $3 \mathrm{~m}$ depth and receives high sedimentary inputs $\left(10 \mathrm{~g}\right.$ dry weight $[D W] \mathrm{m}^{-2} \mathrm{~d}^{-1}$, M. Holmer et al. unpubl. data). The $P$. oceanica meadow at Cala d'Or is in steady-state growth condition (N. Marbà unpubl. data); it grows at $6 \mathrm{~m}$ depth and receives low sedimentary inputs $\left(2 \mathrm{~g} D W \mathrm{~m}^{-2} \mathrm{~d}^{-1}\right.$, M. Holmer et al. unpubl. data) and has been invaded by patches of C. taxifolia since 1992 (T. Grau pers. comm.). The $P$. oceanica meadow at Cala Estancia grows at $3 \mathrm{~m}$ depth in front of a highly developed

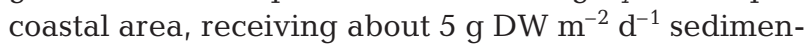
tary inputs (M. Holmer et al. unpubl. data), and the presence of C. racemosa has been recorded since 1998 (T. Grau pers. comm.). In all meadows studied Caulerpa spp. grow as monospecific patches on sandy areas, on dead P. oceanica rhizomes, as well as mixed with $P$. oceanica. The study was conducted during July 2005 , the time of the year when the biomass of all 3 Caulerpa spp. (Terrados \& Ros 1991, Thibaut et al. 2004, Ruitton et al. 2005) and bacterial activity are the highest (Hobbie \& Cole 1984).

Sampling. At each meadow we selected 2 sampling sites (hereafter called stations), one where Posidonia oceanica was growing monospecifically, and one where $P$. oceanica and Caulerpa spp. were growing together. At each station, we collected 3 sediment cores of $4.5 \mathrm{~cm}$ diameter, $10 \mathrm{~cm}$ long, to estimate sediment density and porosity, and 3 sediment cores of $2.6 \mathrm{~cm}$ diameter, $20 \mathrm{~cm}$ long, to quantify SSP and SRR. At each station, we harvested 12 P. oceanica vertical shoots that were transported to the laboratory in seawater, where their meristematic activity was analysed immediately.

SRR and SSP. These were quantified according to the 2-step procedure (acid volatile sulfides, AVS, and chromium reducible sulfur, CRS; Fossing \& Jørgensen 1989). Sulfide concentrations were measured by the spectrophotometric method (Cline 1969), and SSR were calculated according to Jørgensen (1978). Only rates and pools from the AVS fraction are used here $\left(\mathrm{SRR}_{\mathrm{AVS}}\right.$ and $\left.\mathrm{SSP}_{\mathrm{AVS}}\right)$.

Meristematic activity. The activity of Posidonia oceanica rhizome meristems was estimated by quanti- 

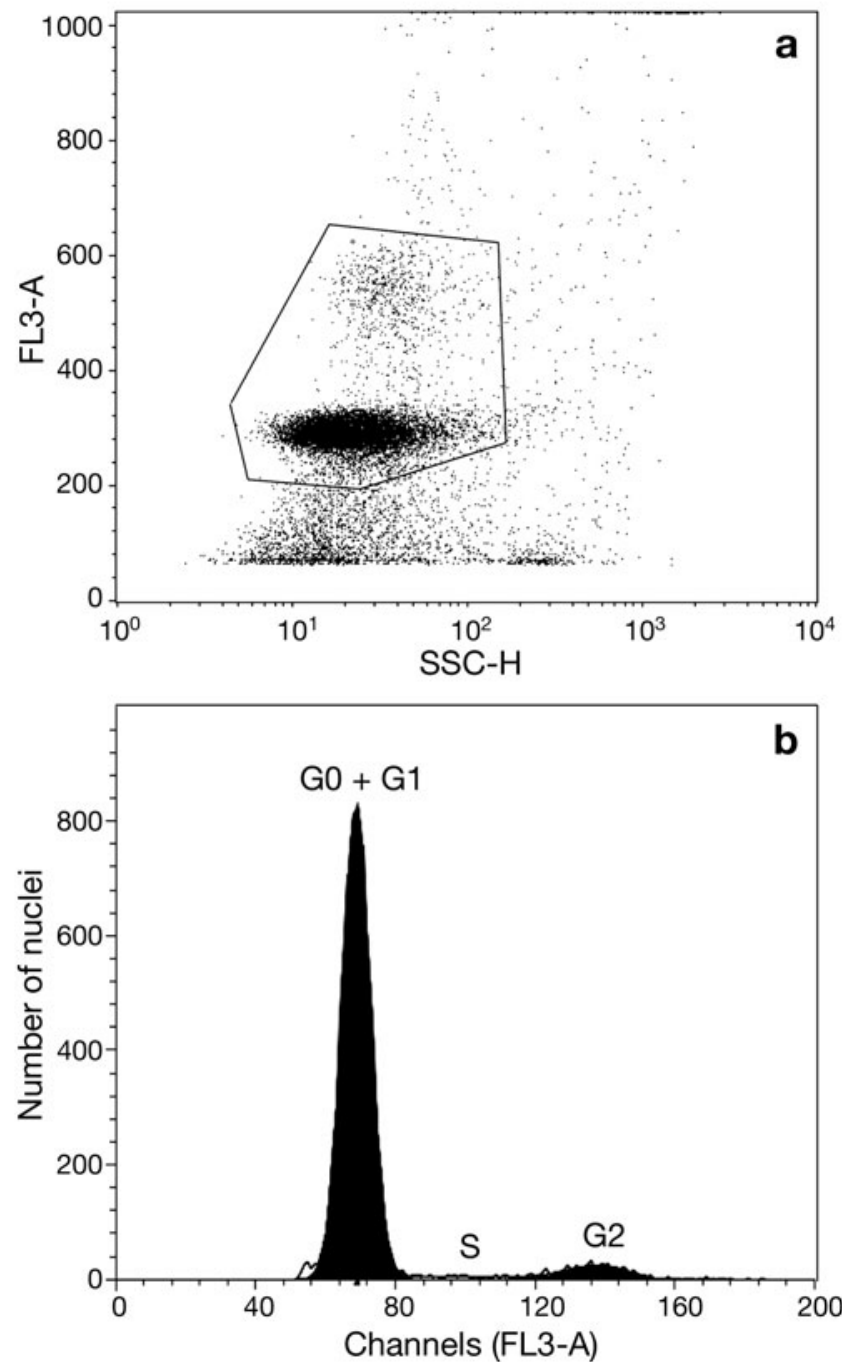

Fig. 1. Posidonia oceanica. (a) Red fluorescence (FL3-A) vs. side scatter (SSC-H) of the nuclei extracted from the P. oceanica meristematic zone, measured with the flow cytometer; the polygon encloses the nuclei in the sample. (b) Histogram of nuclei fluorescence (FL3-A) used to estimate the percentage of nuclei in cell cycle phases (G0 + G1, G2, S)

fying the percentage of nuclei in each phase of the cell cycle (i.e. G0 + G1, S, G2). Samples of $0.5 \mathrm{~cm} \times 1 \mathrm{~cm}$ from the rhizome meristematic zone were cut. The nuclei were isolated using a Partec ${ }^{\circledR}$ extraction kit and stained with propidium iodide (PI) for $1 \mathrm{~h}$ in darkness at $4^{\circ} \mathrm{C}$. The number of nuclei in each phase of the cell cycle (i.e. G0 + G1, S, G2) was quantified using a BecktonDickinson flow cytometer equipped with an argon-ion laser measuring the red fluorescence emitted by the PI. For each meristem 10000 nuclei were analysed (Fig. 1a). The histograms of nuclei fluorescence obtained from the flow cytometer were analyzed using cell cycle analysis software (ModFit), which provided the percentage of nuclei in $\mathrm{G} 0+\mathrm{G} 1, \mathrm{~S}, \mathrm{G} 2$ phases of each meristem sampled (Fig. 1b).

Statistics. We assessed the statistical significance of the variability in the percentage of Posidonia oceanica nuclei in each cell cycle phase, and sediment AVS pools and SRR, among stations (i.e. presence/absence of Caulerpa sp.) and meadows using a 2-way ANOVA. The significance of differences between stations and meadows was assessed using Tukey's post-hoc test. We tested the relationships between $P$. oceanica meristematic activity and SSP and SRR using least square regression analysis on log-transformed variables to meet the requirements of the analysis.

\section{RESULTS}

$\mathrm{SSP}_{\mathrm{AVS}}$ and $\mathrm{SRR}_{\mathrm{AVS}}$ ranged between 0.029 and $226 \mathrm{mmol} \mathrm{SSP}_{\mathrm{AVS}} \mathrm{m}^{-2}$, and 0.086 and $64.37 \mathrm{mmol} \mathrm{SRR}_{\mathrm{AVS}}$ $\mathrm{m}^{-2} \mathrm{~d}^{-1}$ across stations and meadows. SSP $\mathrm{AVs}$ were significantly higher in the sediments colonised by Caulerpa spp. at Cala Llonga when compared with those from the rest of stations and meadows (Table 1, Fig. 2). The differences in $\mathrm{SSP}_{\mathrm{AvS}}$ observed across meadows and stations reflected differences in $\mathrm{SRR}_{\mathrm{AVS}}$, as the highest rates were observed at Cala Llonga when sediments were colonised by Caulerpa spp., and the lowest ones in both

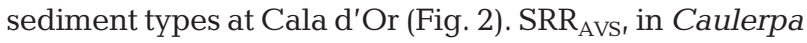
spp. sediments at Cala Llonga and Cala Estancia were significantly higher than those at the rest of stations and meadows (Fig. 2, Table 1). The sediments colonised by Caulerpa species mixed with Posidonia oceanica exhib-

Table 1. Summary of the factorial 2-way ANOVA to assess significant differences in meristematic variables of Posidonia oceanica (cell cycle phases G0 + G1, S, G2) and sediment variables (sediment sulfide pools [ $\mathrm{SSP}_{\mathrm{AVS}}$ ] and sulfate reduction rates $\left[\mathrm{SRR}_{\mathrm{AVS}}\right]$ ) between stations (presence/absence of Caulerpa spp.) and meadows (Cala Llonga, Cala d'Or and Cala Estancia). p provided by a univariate $F$-test

\begin{tabular}{|llccc|}
\hline \multirow{2}{*}{ Variable } & Effect & df & $F$ & $\mathrm{p}$ \\
\hline SSP $_{\text {AVS }}$ & Station & 1 & 28.61 & $<0.0005$ \\
& Meadow & 2 & 0.20 & $\mathrm{~ns}$ \\
& Station $\times$ Meadow & 2 & 9.59 & $<0.005$ \\
SRR $_{\text {AVS }}$ & Station & 1 & 15.95 & $<0.005$ \\
& Meadow & 2 & 0.11 & $\mathrm{~ns}$ \\
$\mathrm{G} 0+\mathrm{G} 1$ & Station $\times$ Meadow & 2 & 4.33 & $<0.05$ \\
& Station & 1 & 0.17 & $\mathrm{~ns}$ \\
& Meadow & 2 & 2.38 & $\mathrm{~ns}$ \\
$\mathrm{G} 2$ & Station $\times$ Meadow & 2 & 1.51 & $\mathrm{~ns}$ \\
& Station & 1 & 0.56 & $\mathrm{~ns}$ \\
$\mathrm{~S}$ & Meadow & 2 & 11.75 & $<0.0001$ \\
& Station $\times$ Meadow & 2 & 0.52 & $\mathrm{~ns}$ \\
& Station & 1 & 0.46 & $\mathrm{~ns}$ \\
& Meadow & 2 & 2.67 & $\mathrm{~ns}$ \\
& Station $\times$ Meadow & 2 & 0.84 & $\mathrm{~ns}$ \\
\hline
\end{tabular}



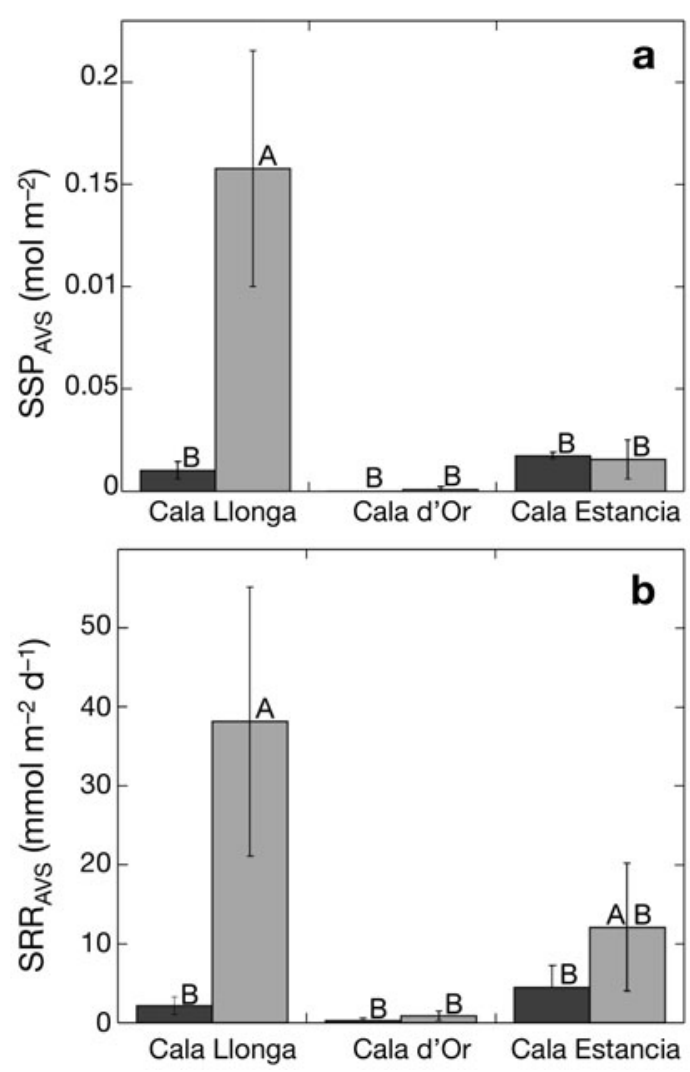

Fig. 2. Posidonia oceanica. Mean \pm SE of (a) sediment sulfide pools $\left(\mathrm{SSP}_{\mathrm{AVS}}\right)$ and (b) sulfate reduction rates $\left(\mathrm{SRR}_{\mathrm{AVS}}\right)$ in the top $10 \mathrm{~cm}$ sediment where $P$. oceanica was growing monospecifically (black bars) and mixed with Caulerpa species (grey bars) $(\mathrm{n}=3)$. A, B indicate significantly different $\mathrm{SSP}_{\mathrm{AVS}}$ and $\mathrm{SRR}_{\mathrm{AVS}}$ across meadows and stations (Tukey post-hoc test)

ited $\mathrm{SSP}_{\mathrm{Avs}}$ up to 15.2-fold higher than those colonised only by $P$. oceanica. $\mathrm{SRR}_{\mathrm{AVS}}$ in sediments colonised by Caulerpa species mixed with $P$. oceanica were between 2.7 to 17.5 -fold higher than those in adjacent sediments colonised by $P$. oceanica alone.

The meristems of Posidonia oceanica presented between 86.0 and $90.9 \%$ of nuclei in phase G0 + G1, 2.0 and $7.0 \%$ in phase $\mathrm{S}$, and 4.7 and $10.2 \%$ in phase G2 of the cell cycle. There were no significant differences (Table 1) in the percentage of nuclei in phases G0 + G1 and S across P. oceanica meadows. Similarly, the presence of Caulerpa species did not affect significantly the percentage of nuclei in $\mathrm{G} 0+\mathrm{G} 1$ and $\mathrm{S}$ phases (Fig. 3, Table 1). Conversely, the percentage of nuclei in phase G2 in the meristems of $P$. oceanica growing at Cala d'Or was significantly 1.5-fold higher than those colonizing Cala Llonga and Cala Estancia (Fig. 3, Table 1). The percentage of nuclei in phase G2 in the meristems of $P$. oceanica tended to decrease when growing with Caulerpa species (Fig. 3), although this trend was not statistically significant (Table 1).
The variability observed in the percentage of dividing cells (i.e. containing nuclei in phase G2) in Posidonia oceanica meristems was closely ( $>80 \%$ of total variance) coupled to variability in $\mathrm{SSP}_{\mathrm{AVS}}$ and $\mathrm{SRR}_{\mathrm{AVS}}$ (Fig. 4). The percentage of nuclei in G2 phase declined with increasing $\mathrm{SSP}_{\mathrm{AVS}}$ and $\mathrm{SRR}_{\mathrm{AVS}}$, reaching the lowest values $(<5 \%)$ when plants were growing on sediments with $\mathrm{SSP}_{\text {AVs }}$ greater than $0.001 \mathrm{~mol} \mathrm{AVS} \mathrm{m}{ }^{-2}$ (Fig. 4). No relationship was observed between the variability in the percentage of nuclei in G0 + G1 and S phases and sediment sulfur dynamics (regression analysis, $p>0.05$ ).

\section{DISCUSSION}

The percentage of nuclei in G2 in Posidonia oceanica meristems is low, particularly when compared with estimates for other plants. For instance, the percentage of dividing cells in leaves of Nicotiana tabacum is 22 to $27 \%$ (Galbraith et al. 1983, Chen et al. 2001). The low fraction of dividing cells in $P$. oceanica rhizome meris-
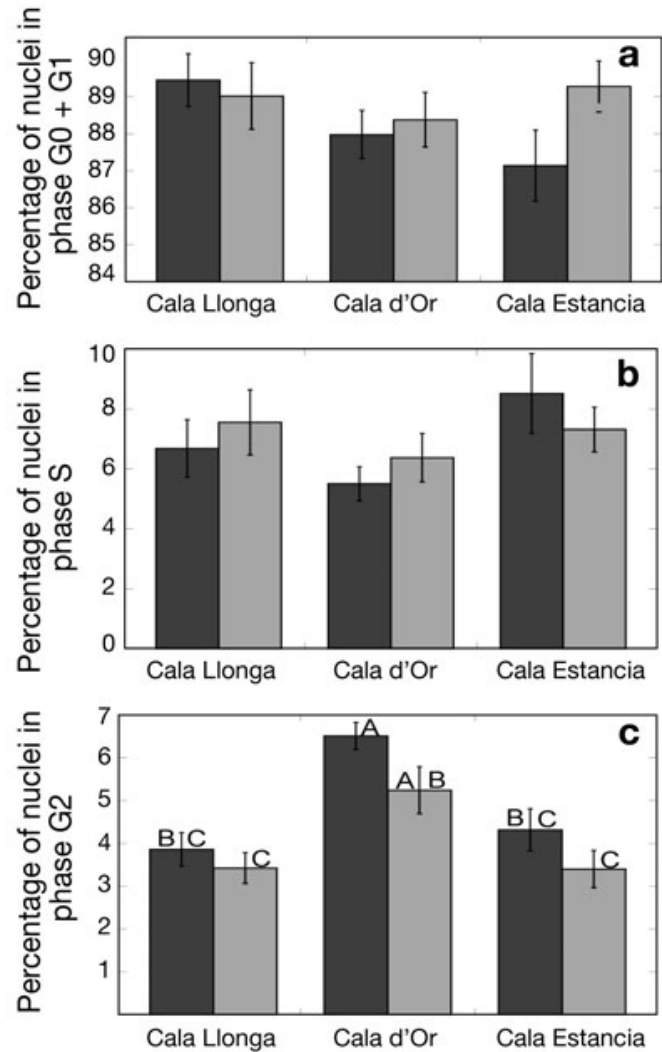

Fig. 3. Posidonia oceanica. Mean \pm SE percentage of nuclei of $P$. oceanica meristems in the (a) G1 + G0 phase, (b) S phase and (c) G2 phase growing monospecifically (black bars) and mixed with Caulerpa species (grey bars) at the study sites ( $\mathrm{n}=$ 12). A, B, C indicate significantly different percentage of nuclei in G2 phase across meadows and stations (Tukey posthoc test); variability in G0 + G1 and S phases across meadows and stations was not statistically different 
tems is consistent with the slow growth of this species (rhizome growth rate: $4.2 \mathrm{~cm} \mathrm{yr}^{-1}$, leaf growth: $1.3 \mathrm{~mm}$ leaf ${ }^{-1} \mathrm{~d}^{-1}$; Duarte 1991), which ranks amongst the slowest-growing angiosperms (Nielsen et al. 1996).

Despite the low fraction of dividing cells in Posidonia oceanica meristems, the fraction of cells in the G2 phase varied by up to $50 \%$ across stations and meadows (Fig. 3). The variability in the percentage of dividing cells in $P$. oceanica meristems mainly reflected differences between sites (Table 1), the meristems in plants at Cala d'Or exhibiting a larger fraction of nuclei in the G2 phase than those at Cala Llonga and Cala Estancia. Despite the fact that the presence of Caulerpa spp. did not have a statistically significant effect on the percentage of nuclei in the G2 phase in $P$. oceanica meristems (Table 1), the activity of seagrass meristems displayed lower values when growing with Caulerpa spp. than in monospecific stations at all 3 sites (Fig. 3). Recently, M. Holmer et al. (unpubl. data)

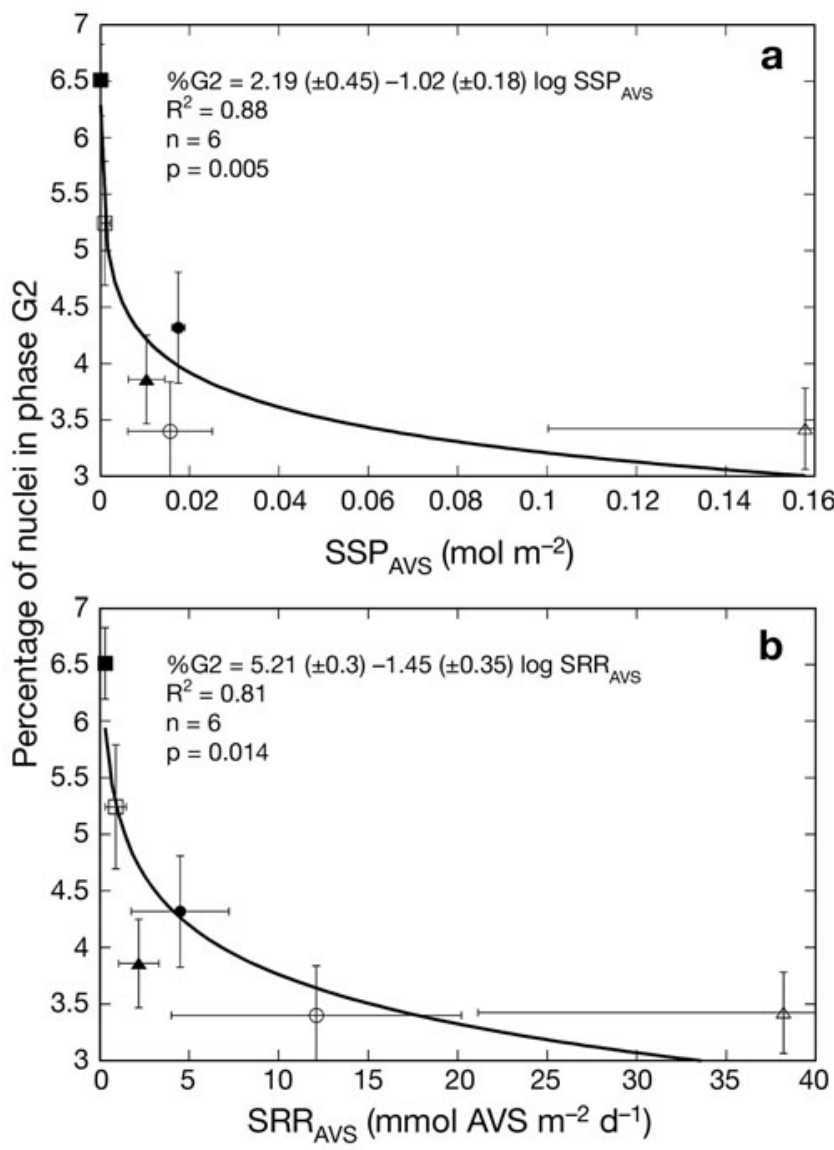

Fig 4. Posidonia oceanica. Relationship between the percentage of nuclei of $P$. oceanica meristems in the G2 phase and (a) sulfide sediment sulfide pools $\left(\mathrm{SSP}_{\mathrm{AVS}}\right)$ and (b) sulfate reduction rates $\left(\mathrm{SRR}_{\mathrm{AVS}}\right)$ in monospecific (black symbols) and mixed (open symbols) meadows at Cala Llonga $(\Delta)$, Cala d'Or $(\square)$ and Cala Estancia (O). Standard errors of the mean values are shown $\left(\mathrm{n}_{\mathrm{G} 2}=12 ; \mathrm{n}_{\mathrm{AVS}}=3 ; \mathrm{n}_{\mathrm{SRR}}=3\right)$ found that Caulerpa spp. enhance sulfate reduction rate and anoxia in the sediments they colonise, and a strong coupling between Caulerpa spp. biomass and sulfate reduction rate and sediment anoxia. The lower percentages of G2 nuclei in meristems of $P$. oceanica in the presence of Caulerpa spp. as opposed to seagrass growing alone, albeit not statistically significant (Fig. 3), suggests that P. oceanica health is compromised by Caulerpa spp. invasions, due to the increase in sediment sulfides, and it supports the hypothesis that Caulerpa spp. act as ecological engineers (M. Holmer et al. unpubl. data), excluding P. oceanica by deteriorating sediment conditions .

The close and negative relationship between the percentage of dividing cells in Posidonia oceanica meristems and sediment sulfide concentrations and production reflects the high sensitivity of seagrasses to sulfides. Sulfide intrusion in seagrass tissues has been observed in Zostera marina (Pedersen et al. 2004), Thalassia testudinum (Borum et al. 2005) and P. oceanica (Frederiksen et al. 2007, Marbà et al. 2007). Mass balance computations based on $\delta^{34} \mathrm{~S}$ signals in $P$. oceanica tissues and the potential sulfur sources (sediment porewater sulfides and seawater sulfate) showed that sulfide intrusion accounts for up to $40 \%$ of total plant sulfur at Cala Llonga (M. Holmer et al. unpubl. data), the location that supported the plants with meristems with the least percentage of dividing cells (Fig. 3).

The percentage of dividing cells in Posidonia oceanica meristems decreased sharply when $\mathrm{SSP}_{\mathrm{AVS}}$ and $\mathrm{SRR}_{\mathrm{AVS}}$ increased (Fig. 4). The stability of $P$. oceanica meadows is closely related to sediment sulfide pools, accelerating meadow decline rates when sediment sulfide concentration exceeds $10 \mu \mathrm{M}$ (Calleja et al. 2007). Considering that $10 \mu \mathrm{M}$ of $\mathrm{H}_{2} \mathrm{~S}$ equals $0.001 \mathrm{~mol} \mathrm{AVS} \mathrm{m}^{-2}$ (calculated using the water content and sediment density, and assuming that all $\mathrm{SSP}_{\mathrm{Avs}}$ within the top $10 \mathrm{~cm}$ sediment layer was released as $\mathrm{H}_{2} \mathrm{~S}$ in the porewater), our results (Fig. 4) indicate that $P$. oceanica meristems with less than about $5 \%$ nuclei in the G2 phase are under sulfide stress. Hence, there is a potential for seagrass meristematic activity to be used as an early warning indicator of plant health and meadow decline.

In summary Posidonia oceanica meristems divide slowly, as the percentage of cells in the G2 phase was $<7 \%$, below that observed for meristems of any other plant. $P$. oceanica meristematic activity, assessed as the percentage of nuclei in the G2 phase, is closely coupled to sediment sulfur dynamics, the percentage of nuclei decreasing when $\mathrm{SSP}_{\mathrm{Avs}}$ exceeds $0.001 \mathrm{~mol}$ AVS $\mathrm{m}^{-2}$. These findings confirm that seagrass meristematic activity is highly sensitive to increased sulfide and points at seagrass meristematic activity as an indicator of plant stress and seagrass health, as well as an early warning indicator of seagrass decline. 
Acknowledgements. This work was funded by the European Network of Excellence MarBEF, Fundación BBVA, and the Spanish Ministry of Education and Science (CTM200501434/MAR). We thank L. Navarro, and O. Olivares for initial discussions on plant meristematic activity, S. Agustí for advice on flow cytometry techniques, and T. Grau for providing information on arrival dates of invasive Caulerpa spp. at the locations studied. We are grateful to $\mathrm{M}$. Lamote for field and laboratory assistance, and 3 anonymous reviewers for their comments which helped to improve the manuscript. N.G-B. was supported by a PhD grant from the Government of the Balearic Islands (reference FPI04 43126005Q).

\section{LITERATURE CITED}

Borum J, Pedersen O, Greve TM, Frankovich TA, Zieman JC, Fourqurean JW, Madden CJ (2005) The potential role of plant oxygen and sulphide dynamics in die-off events of the tropical seagrass, Thalassia testudinum. J Ecol 93: $148-158$

Calleja ML, Marbà N, Duarte CM (2007) The relationship between seagrass (Posidonia oceanica) decline and porewater sulfide pools in carbonate sediments. Estuar Coast Shelf Sci 73:583-588

Chen JG, Shimomura S, Sitbon F, Sandberg G, Jones AM (2001) The role of auxin-binding protein 1 in the expansion of tobacco leaf cells. Plant J 28:607-617

Cline JD (1969) Spectrophotometric determination of hydrogen sulfide in natural waters. Limnol Oceanogr 14:454-458

> Duarte CM (1991) Allometric scaling of seagrass form and productivity. Mar Ecol Prog Ser 77:289-300

Duarte CM, Holmer M, Marbà N (2005) Plant-microbe interactions in seagrass meadows. In: Kristensen E, Kostka JE, Haese RH (eds) Macro- and microorganisms in marine sediments. Coastal and Estuarine Studies, American Geophysical Union, Washington, DC, p 31-60

Fossing H, Jørgensen BB (1989) Measurement of bacterial sulfate reduction in sediments - evaluation of a singlestep chromium reduction method. Biogeochemistry 8: 205-222

Frederiksen MS, Holmer M, Díaz-Almela E, Marbà N, Duarte CM (2007) Sulfide invasion in the seagrass Posidonia oceanica at Mediterranean fish farms: assessment using stable sulfur isotopes. Mar Ecol Prog Ser 345:93-104

Galbraith DW, Harkins KR, Maddox JM, Ayres NM, Sharma DP, Firoozabady E (1983) Rapid flow cytometric analysis of the cell cycle in intact plant tissues. Science 220:1049-1051

Goodman JL, Moore KA, Dennison WC (1995) Photosynthetic responses of eelgrass (Zostera marina L.) to light and sediment sulfide in a shallow barrier island lagoon. Aquat Bot 50:37-47

Hemminga MA, Duarte CM (2000) Seagrass ecology. Cambridge University Press, Cambridge

Editorial responsibility: Hans Heinrich Janssen, Oldendorf/Luhe, Germany
Hobbie JE, Cole JJ (1984) Response of a detrital foodweb to eutrophication. Bull Mar Sci 35:357-363

Holmer M, Duarte CM, Marbà N (2003) Sulfur cycling and seagrass (Posidonia oceanica) status in carbonate sediments. Biogeochemistry 66:223-239

Holmer M, Duarte CM, Boschker HTS, Barrón C (2004) Carbon cycling and bacterial carbon source in pristine and impacted Mediterranean seagrass sediments. Aquat Microb Ecol 36:227-237

Jørgensen BB (1978) Comparison of methods for the quantification of bacterial sulfate reduction in coastal marine sediments. 1. Measurements with radiotracer techniques. Geomicrobiol J 1:11-27

> Le Gall Y, Brown S, Marie D, Mejjad M, Kloareg B (1993) Quantification of nuclear DNA and G-C content in marine macroalgae by flow cytometry of isolated nuclei. Protoplasma 173:123-132

Marbà N, Calleja ML, Duarte CM, Álvarez E, Díaz-Almela E, Holmer M (2007) Iron additions revert seagrass (Posidonia oceanica) decline in carbonate sediments. Ecosystems 10: $745-756$

Nielsen SL, Enríquez S, Duarte CM, Sand-Jensen K (1996) Scaling of maximum growth rates across photosynthetic organisms. Funct Ecol 10:167-175

> Orth RJ, Carruthers TJB, Dennison WC, Duarte CM and others (2006) A global crisis for seagrass ecosystems. Bioscience 56:987-996

Pedersen O, Binzer T, Borum J (2004) Sulphide intrusion in eelgrass (Zostera marina L.). Plant Cell Environ 27: 595-602

Raven JA, Scrimgeour CM (1997) The influence of anoxia on plants of saline habitats with special reference to the sulphur cycle. Ann Bot (Lond) 79:79-86

Ruitton S, Verlaque M, Boudouresque CF (2005) Seasonal changes of the introduced Caulerpa racemosa var. cylindracea (Caulerpales, Chlorophyta) at the northwest limit of its Mediterranean range. Aquat Bot 82:55-70

Terrados J, Ros JD (1991) Production dynamics in a macrophyte-dominated ecosystem: the Mar Menor coastal lagoon (SE Spain). Oecol Aquat 10:255-270

> Terrados J, Duarte CM, Kamp-Nielsen L, Agawin NRS and others (1999) Are seagrass growth and survival constrained by the reducing conditions of the sediment? Aquat Bot 65: 175-197

> Thibaut T, Meinesz A, Coquillard P (2004) Biomass seasonality of Caulerpa taxifolia in the Mediterranean Sea. Aquat Bot 80:291-297

> Tomlinson PB (1974) Vegetative morphology and meristem dependence. The foundation of productivity in seagrasses. Aquaculture 4:107-130

Yanpaisan W, King NJC, Doran PM (1998) Analysis of cell cycle activity and population dynamics in heterogeneous plant cell suspensions using flow cytometry. Biotechnol Bioeng 58:515-528

Submitted: November 16, 2007; Accepted: August 28, 2008 Proofs received from author(s): November 17, 2008 